\title{
How to Survive Your Freshman Year (Fourth Edition)
}

\author{
by Scott Silverman and Frances Northcutt (eds.)
}

Published by Hundreds of Heads Books, LLC, 2010, 367 pages

Reviewed by

Katherine Mooney, student, University of Notre Dame, psychology and pre-med studies

Amber Stedman, student, Northern Illinois University, biological sciences

The transition to college is one of the most exciting and challenging times in a young adult's life. In the freshman year, students must learn how to adjust academically, socially, and physically to their new environment, balancing newfound freedoms with responsibilities. No two college experiences are exactly alike; therefore, the best advice for each student will vary. This is perhaps one of the most difficult aspects of the college transition-sorting through the advice and finding those pieces which serve as the best guide for the individual. In How to Survive Your Freshman Year, editors Scott Silverman and Frances Northcutt compiled quotations and pieces of advice from current college students, recent graduates, and student affairs professionals. This collaborative work provides a variety of perspectives on topics relevant to college freshmen including leaving home, residence hall life, and roommates, classes and studying, socializing and extracurricular activities, finances, and communicating with friends and family. From these many viewpoints, readers can select the information most pertinent to their college life.

Overall, the book has an objective and unbiased tone largely due to the inclusion of advice from a variety of sources. The student contributors come from an array of ethnic backgrounds and represent public and private institutions from all regions of the country. Participating institutions also varied with respect to religious or secular affiliation and the size of the student body. While the majority of the book is comprised of student quotations, each chapter begins with a "Headlines" section which details main points and themes. Interspersed are subsections of expert advice written by the editors and others involved in student affairs. While we would not have found all advice pertinent or helpful to our own freshman experiences, we, the reviewers, have grouped chapters with similar themes and highlighted what we believe to be the most useful sections for incoming students and student affairs professionals.

The book begins by discussing the challenges associated with leaving home and learning to live in a college environment. Packing-a daunting task for any 
new student-is discussed extensively. Included is a list of all the essential items and several quotations from students describing their "must-have" college items. More importantly, the book mentions the significance of bringing intangible items such as good judgment, maturity, patience, and sense of self. We feel that this section, perhaps more than any other in the book, provides valuable insight into what determines students' overall success. In our experience as college students, forgetting these intangibles leads to difficulties that may have been otherwise avoided.

Saying good-bye to parents and siblings is another freshman worry described by the student contributors. Most suggest making the farewell period brief and planning activities with other new students after parents leave. While these personal accounts offer less specific advice than that in other chapters, students may find it helpful to know how others have overcome the uncertain first days of college.

After students are settled, there are often a few days before classes begin. The book advises students to use this time as an adjustment period by making every effort to become acquainted with the campus layout and transportation routes. Students are also urged to attend their orientation and transition programs where they will learn essential information about campus requirements and resources. While many students quoted that some orientation activities seem "silly," most acknowledge that orientation helped them meet their fellow classmates and become comfortable in their new environment (p. 40).

Next, the editors turn to the topic of residence hall life, perhaps the most anticipated change for freshmen who have been accustomed to living at home and having private space. Overall, commentators have a positive opinion of residence halls, especially freshmen-only halls where students tend to feel particularly connected to one another. Getting to know fellow residents and hall staff members is mentioned by multiple students as a way to ease the discomforts of communal living.

Freshmen are notoriously anxious about roommate relationships and many feel pressure to have a certain kind of relationship. The book suggests not entering into the situation with any premature expectations. Instead, freshmen should begin by agreeing on a set of ground rules which everyone can abide by. Furthermore, they should not expect to become best friends with their roommate; they should merely hope to maintain a comfortable living environment together. However, if roommate arrangements become intolerable, the book reminds students that they can request a room change. In our opinion, the combination of quotations used for this section accurately reflects the variety of roommate relationships that can materialize.

Several chapters are devoted to classes and study techniques. One common theme is the increase in academic responsibility that should and usually does accompany the transition to college. In contrast to high school, college students have significant freedom to select classes, decide whether to attend class, and manage study time. The book emphasizes the need to balance these newfound freedoms with good time management and organizational skills. For example, 
student contributors suggest designating a specific time and location for studying and allocating sufficient time to complete assignments. Regular class attendance and frequent communication with professors are cited as other keys to academic success.

While we found the student advice on academics to be useful, we were particularly impressed with the section titled " 4 Tips to Improve Reading Skills in College" by David Rothman and Jilani Warsi from Queensborough Community College. The tips include making note cards for new vocabulary, avoiding distractions, re-reading important sections or chapters, and speaking with professors individually for further clarification. Implementing these strategies would be helpful for all college freshmen.

Several students also recommend study abroad and service learning programs as ways to enhance education beyond the classroom. By living and learning in different environments, students seem to develop new and mature perspectives on their lives and the lives of others. Students considering study abroad may benefit from the "Study-Abroad List" compiled by the editors; the concise outline lists important questions applicants should ask themselves and their advisor.

Aside from managing classes and studying, students must also find time for co-curricular activities. The book encourages students to join clubs and campus organizations as a way to meet peers with similar interests and explore activities unavailable in high school. Contributors share their experiences in a variety of activities including academic, athletic, social, and volunteer organizations. Students involved in volunteer organizations expressed great enthusiasm, many saying that volunteer work helped them find their passion and become more involved with their community. For students interested in promoting a cause, the section, "Making Your Mark: Community Involvement" by editor Silverman, provides step-by-step instructions on how to develop an idea and find resources.

Additionally, for students who have researched campus organizations and still have not found something which suits their needs or interests, the book provides ideas on how to start your own club.

One section we found particularly applicable given recent suicides in young members of the LGBT community is "Tips for LGBT Students" by Justin Long, Assistant Director for Assignments \& Student Relations at The University of Southern Mississippi. This section addresses the challenges LGBT students are likely to face and provides suggestions for building a strong support network.

Most freshmen are eager to join the college party scene, and in their efforts to find social acceptance, some inevitably forget to make responsible choices. However, most student commentators discuss safe partying and alcohol consumption, urging new students to balance schoolwork and social time. Editor Northcutt also includes a section reminding students to become familiar with university and residence hall alcohol policies and to avoid engaging in high-risk activities. Several student writers warn women to take special caution when attending parties by keeping track of beverages and traveling in trusted groups. While we would agree that women should be cautious and alert, we were disappointed to find no messages on responsible socializing addressed to men. 
College dating is another topic discussed in sections dealing with social life. Generally, student writers advise freshmen not to date in their first year, especially during the first semester. Those who begin dating too early seem to have more difficulty adjusting to other aspects of college life and are less likely to be involved in extracurricular activities. Contributors warn against long distance relationships for similar reasons. If freshmen do decide to date, they are advised to date other freshmen who do not live in their residence hall or on their floor.

For today's college students, online social networking facilitates both old and new relationships. Although communication through Facebook, Twitter, and Skype can be a useful tool for keeping in touch with family and friends, many students admit that networking websites can become distracting and should be used in moderation. Students are advised to be cautious and use privacy settings when posting pictures and written material since anyone, including potential employers and school officials, may view these websites. Special sections such as "Tag: You're It" by contributors Elizabeth Lovett, Angie Mock, and Robert Rhu and "Social Networking 101" by editor Silverman give more detailed advice on what is appropriate to post online.

The college finance section gives tips on sticking to a budget and balancing work with academic demands. For example, readers are advised to use their meal plan, avoid credit card offers, and look for on-campus jobs. One section we found particularly useful was "Money Management 101" by editor Silverman which includes a budget chart that covers all major college expenses. Students are also urged to take advantage of their campus career center and Federal Work-Study (FWS) programs if they qualify. Included is a section by Dr. Pamela Golubski of Carnegie Mellon University describing common work-study positions and explaining how to apply. The finance section closes by reminding students to limit time spent working, coordinate work with school schedules, and communicate with supervisors.

While family members and friends from home can serve as an essential support system for college freshmen, many students struggle to keep in close contact while maintaining independence. One of the final chapters describes the best ways for college students to stay connected with those at home without feeling tied down. Many who prefer electronic communication use e-mail, Facebook, or text messaging, whereas those who prefer phone conversations suggest scheduling a weekly time to talk with family and friends. No matter the method, frequent communication not only puts parents at ease, but also helps students through stressful situations. That being said, student commentators caution against becoming too reliant on family and strongly suggest acquiring new social contacts distinct from those made in high school.

How to Survive Your Freshman Year provides student viewpoints and expert advice on virtually every topic pertaining to first-year students from moving in to finding meals. Some readers may find certain viewpoints to be conflicting or insignificant. In addition, many student comments were specific to their university and would not be applicable to others. However, this book intentionally provides varying perspectives so that students may follow the advice most relevant to their 
own situation.

While a multitude of topics were covered, we believe that some relevant and contemporary issues were left out or discussed insufficiently. For instance, attaining a diverse student body and promoting cultural exposure is a priority at most institutions, yet these topics are only briefly mentioned. Other important information such as the frequency of binge drinking among college students was provided but without proper citations or, in some cases, from questionable sources such as Playboy magazine or Wikipedia. There were also certain discussions which we feel would have benefitted from more statistical evidence, such as sexual assault among college females.

We would recommend this book primarily for high school seniors as they transition to college. Because of the emphasis on residence hall life, roommates, and leaving home, students living on their college campuses may find this book more useful than those who commute. Likewise, transfer students may have different concerns than those addressed in this book; they may need less advice on college living and more suggestions on adjusting to a new college environment. Other types of non-traditional students including veterans, students with families, and those entering from the workforce would not find information in this text applicable to their unique situations.

Orientation leaders and student affairs professionals might read How to Survive Your Freshman Year to better understand student concerns and perspectives. However, this text would be difficult to use in a first-year seminar due to the inclusion of personal accounts in place of well developed ideas. Instructors may find it more appropriate for individual reading or pre-college projects. After reading this book students will be aware of the realities of college life and better prepared to shape their own unique college experience. 